\title{
Relationship between landslide and morpho-structural analysis: a case study in Northeast of Morocco
}

\author{
Brahim Benzougagh ${ }^{1} \cdot$ Sarita Gajbhiye Meshram ${ }^{2,3}$ (1) $\cdot$ Brahim Baamar $^{4} \cdot$ Abdallah Dridri $^{5} \cdot$ Larbi Boudad $^{6}$. \\ Driss Sadkaoui ${ }^{7} \cdot$ Khalid Mimich $^{8}$
}

Received: 22 April 2020 / Accepted: 16 June 2020 / Published online: 30 June 2020

(c) The Author(s) 2020

\begin{abstract}
The study of landslides in the Inaouene watershed (northeastern Morocco) provides information on the relationships between landslides and morpho-structural analysis. Landslides affect part of the slopes and slopes of the valley. The configuration of this relationship is controlled by the combination of several predisposing factors. Two localities were studied, located in similar morpho-structural contexts, but characterized by a different lithology. The first determining factor was lithology, in particular the dominance of friable geological formations, especially marls in the locality of Chebabate and limestone soft formations in the locality of Tahla. The second factor was the tectonics, which is well individualized in the limestone of Tahla; in spite of friable lithology of the marls of Chebabate, one manages to disturb traces of the tectonics notably with the level of intercalation of the sandstone benches. Another factor that controls the dissection and the evolution of the landslides is the precipitation by the effect of abundance of the water of impregnation in the formations. The fieldwork is devoted to the measurement of the different faults encountered in the two localities to make the stereographic projection in order to elaborate canvas. The principal objective of this study is to find the relation between the evolution of the risks of erosion and landslide as well as the various factors, who control their spatiotemporal evolution. The results obtained will help managers and decision-makers in the development of watersheds in order to take the necessary steps to reduce the negative impact of this natural hazard on the environment, the population and their property.
\end{abstract}

Keywords Landslide $\cdot$ Inaouene watershed $\cdot$ Morpho-structural $\cdot$ Tectonic $\cdot$ Natural hazard

\section{Introduction}

Landsliding is one of the most important processes inducing geomorphological changes on slopes in mountainous, hilly and coastal areas (Calista et al. 2019). Landslides in tectonically active mountains are one of the major mass loss

Sarita Gajbhiye Meshram

saritagmeshram@tdtu.edu.vn; gajbhiyesarita@gmail.com

1 Department of Geology, Geoscience Laboratory, Heritage and Useful Substances (GPS), Faculty of Sciences,

University Moulay Ismail, Meknes, Morocco

2 Department for Management of Science and Technology Development, Ton Duc Thang University, Ho Chi Minh City, Vietnam

3 Faculty of Environment and Labour Safety, Ton Duc Thang University, Ho Chi Minh City, Vietnam

4 Department of Geology, Faculty of Sciences, University Moulay Ismail, Meknes, Morocco processes (Hovius et al. 1997; Shroder 1998; Ballantyne 2002; Sanchez et al. 2010; Kumar et al. 2019). The study area is a fragile and vulnerable environment where water erosion causes huge landslides. The slopes of Inaouene River are affected by many ground movements belonging to landslides, landslides and mudslides. Their size varies

5 Department of Geology, Natural Resource Laboratory Environments and Sustainable Developments (RNE2D), Faculty of Sciences Dhar El Mahraz, Sidi Mohamed Ben Abdellah University, Fez, Morocco

6 Department of Geology, Faculty of Sciences, University Mohamed 5, Rabat, Morocco

7 Department of Geology, Faculty of Sciences, University Abdelmalek Essaadi, Tetouan, Morocco

8 Department of Geology, Water Sciences and Environment Engineering Team, Faculty of Sciences, University Moulay Ismail, Meknes, Morocco 
from one sector to another, and their genesis and evolution are controlled by a combination of several predisposing factors including: the lithological nature of formations, slope, tectonic activity (structural setting) and precipitation (abundance of impregnation water $=$ climate), vegetation and land use. Landslides are also largely dependent on the morphostructural setting of the rocks and/or the main joint influencing the rock masses as they strike soft and weak rocks. As a result of these movements, we are witnessing forms of water erosion and we also observe spectacular movements of soils that are catastrophic for the environment, man and their property. In addition to these factors mentioned, there are other factors influencing the development of landslides, which must be taken into consideration, as rainfall infiltration and surface cracks. Surface cracks are due to many factors, such as desiccation, tension, wetting-drying cycles and weathering (Utili 2013; Wu et al., 2015; Song and Cui 2016; Zeng et al. 2018, 2020). Precipitation (rainfall) is a paramount factor in the process of landslide genesis in the study area. The average annual rainfall in the region is about $900 \mathrm{~mm}$ (Benzougagh et al. 2017). The runoff is strongly influenced by the seasonal distribution of precipitation (Gajbhiye et al. 2013; Meshram et al. 2017; Meshram and Meshram 2020). The existence of surface cracks would cause water to quickly penetrate the slope during rainfall. It causes a significant increase in the soil's water content across fractures and the creation of new saturated zones (Zeng et al. 2018; Mukhlisin and Khiyon 2018; Zeng et al. 2020). After runoff, these saturated areas slowly vanish when more rainwater either infiltrates under gravity and capillary impact into the deeper soil or becomes water vapor as the temperature rises. The transient saturated zone increases the weight of the soil and reduces the strength of the soil, so that the soil slope can become unstable. Consequently, the risk of landslide occurs in the study area (Gajbhiye et al. 2014, 2015).

This study deals with the relationships between tectonic activity, risk erosion and landslide triggering as a form of water erosion risk evolution in the Inaouene basin (Northeastern Morocco). From a structural point of view, the watershed of the Inaouene River is part of a junction zone between three structural domains: the Prerif, the South Rifain furrow and the Middle Atlas. The effect of tectonics combined with the lithology of the study area is individualized by the current installation of the dense and branched hydrographic network in this region. Otherwise, this zone has experienced the same evolution as that of the entire subtabular northern part of the Middle Atlas Mountains (Martin 1981). However, its proximity to the South Rifean furrow subjected it to Miocene subsidence. This research consists of a detailed tectonic study of the central part (Tazekka) and downstream (Chebabate) of this basin and with a main objective to clarify the role and contribution of tectonics on the evolution of natural risks (erosion water, landslide). The tectonic analysis is carried out by the use of stereographic projection. In structural geology, stereographic projection is a useful technique for solving many structural problems. It aids Structural Geologists with their research and other objectives (Laik 2016). This includes the planes and lines being drawn on a circular grid or database. There are many software programs, both commercially and as freeware; that will plot and manipulate the stereo net structural data in various and powerful ways. Data analysis involved stereographic projection diagrams and rosette diagrams of system fracture orientations to define essential fracture sets under the effect of these tectonic forces, and in combination with the other factors mentioned, we understand the relationship between tectonics and morpho-structural and the genesis of the risk of landslides in the region.

\section{Geomorphological analysis}

This study is carried out in the catchment area of Inaouene River, which is located in Northeast of Morocco. It is the second subwatershed of Sebou River after that of Ouergha River. It is part of the Province of Taza, Fez-Meknes Region, and covers an area of about $3700 \mathrm{Km}^{2}$ and a perimeter of about $320 \mathrm{~km}$ (Fig. 1). This watershed is limited to the North by the Oued Leben Basin, to the Southwest by the Sebou watershed, to the East by the Moulouya Medium watershed and to the Northwest by the Ouergha High watershed (Benzougagh et al. 2016, 2017). The choice of this zone is justified by its extension over three structurally and lithologically distinct domains (Rif, Prérif and Moyen-Atlas). Understanding the evolution of the erosive processes of the risk of erosion, landslides and floods of this watershed requires an analysis of all the factors involved in these processes.

The basin is not at all morphologically homogeneous: north of the Inaouene valley, the hills of marl and flyschs of the prifain system rise from $500 \mathrm{~m}$ of altitude to the river until $1700 \mathrm{~m}$ in the north. The valleys of the various tributaries oriented roughly North-South; join a base level whose altitude grows less quickly upstream than the altitude of the ridges, although the relief is accentuated from the West toward the East from corrugations to casings.

The watershed of the river Inaouene is subdivided into two parts: in the West a fairly fast sloping plateau to the northwest, culminating at $1750 \mathrm{~m}$ on a ridge, drained by Lahmar River, Matmata, Bou Hellou, that it flows parallel to the northwest. To the east, a mountainous cluster culminating at $2000 \mathrm{~m}$ (Jbel Tazekka) deeply cut by valleys diversely oriented. The Bou Laajraf River basin, which forms the southeast corner of the Inaouene basin, is outside the mountainous zone: Although rising to $1700 \mathrm{~m}$, it is a plateau with an altitude of about $600 \mathrm{~m}$. The Larbaa River 


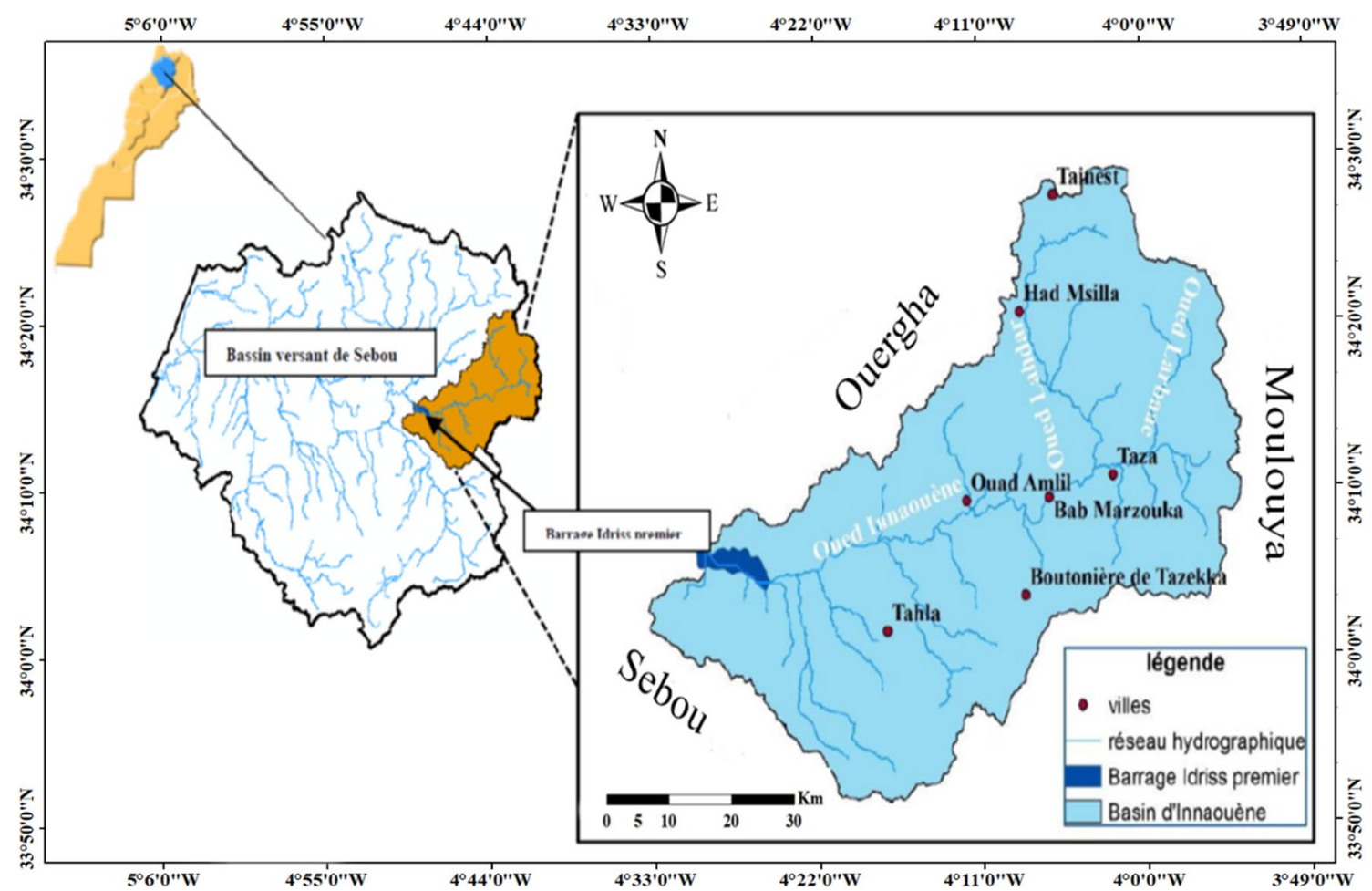

Fig. 1 Location map of Inaouene watershed (study area)

basin, which forms the northwest of the Inaouene River, lies at the edge of the system of the Prerifaines hills and only rises to $1400 \mathrm{~m}$ (Fig. 2).

The hypsometric curve provides a synthetic view of the slope of the basin and represents the distribution of the surface of the watershed according to its altitude.

This watershed is characterized by its geomorphological and geological complexity. Its characteristic morphology with steep terrain, with friable lithological formations, such as marls, marl-limestone and shale, hence an important contribution to the siltation of the Idriss 1st dam located downstream of the Inaouene River. This causes a loss of their equivalent water storage potential of 75 million $\mathrm{m}^{3}$, i.e., a decrease of about $0.5 \%$ per year of the total capacity of the dams, which is 14 billion $\mathrm{m}^{3}$, which translates into a loss of irrigable surface of $600 \mathrm{ha} /$ year.

Thus, it presents a climatic contrast in a semiarid mediterranean climate characterized by annual rainfall irregularities and violent storms causing severe water erosion and torrential floods, as well as subfrequency flooding annual. The
Fig. 2 Hypsometric curve of the Inaouene watershed

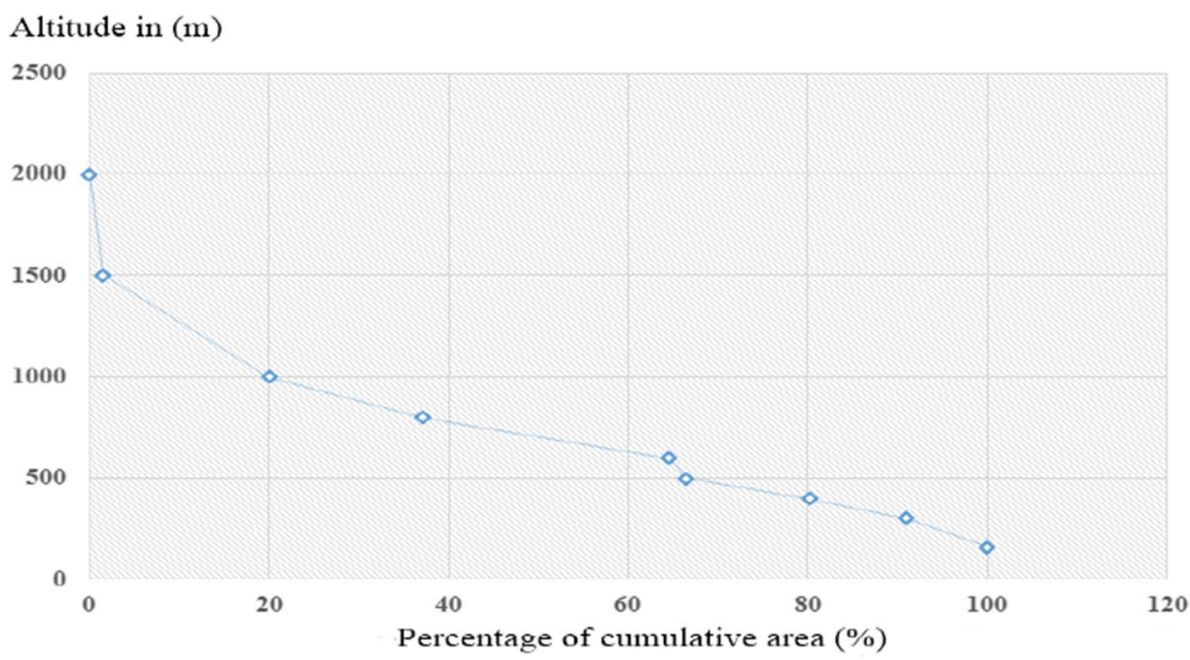


topography of the watershed, whose steep slopes, accelerates the removal of soil particles, especially during low vegetation cover as the case of our basin.

\section{Basin geology}

From a geological and lithological point of view, the basin is very heterogeneous (Fig. 3). It is even difficult to define a few units corresponding to specific morphologies. North of Inaouene, including the Larbaa River basin, extends the area of marls and Cretaceous and Tertiary flyschs whose facies can be very different: rarely schistose, sometimes limestone, more often sandstone. These marls and flyschs are pierced with Triassic saline points and Jurassic limestone chests. The lithology is rapidly changing on the ground and seems to have had no influence on the layout of the Rivers.

North of the Inaouene, the plateau of the western part, includes in its highest part a band of primary schists very damaged, then a plateau itself of limestone karst limestones, plunging to the north, under the marls of the end of the Tertiary which are covered with thick soil. The mountainous cluster includes on the one hand the primary schists of Jbel Tazekka and on the other hand the dolomitic limestones which dominate Taza in the South and where is the large sinkhole of the daya Chicker, whose resurgence forms the Taza River. The Bou Laajraf river basin and the Taza plateau are formed almost entirely of bare marls or with shallow soil.

\section{Tectonic analysis}

The structural context is marked by the predominance of soft materials, mainly marly, in a tormented structure affected by piers (Tribak et al. 2012). We carried out the tectonic analysis in two localities: Chebabate and causse of Tahla.

Locality of Chebabate The geological sections carried out in the locality of Chebabate (southern slope of the Inaouene River) show that the area is occupied by an impermeable marl substratum more or less armed with limestone and sandstone benches (Fig. 4).

It corresponds to a thicker unit with blue marl of Tortonian with thin calcareous and sandstone intercalations.

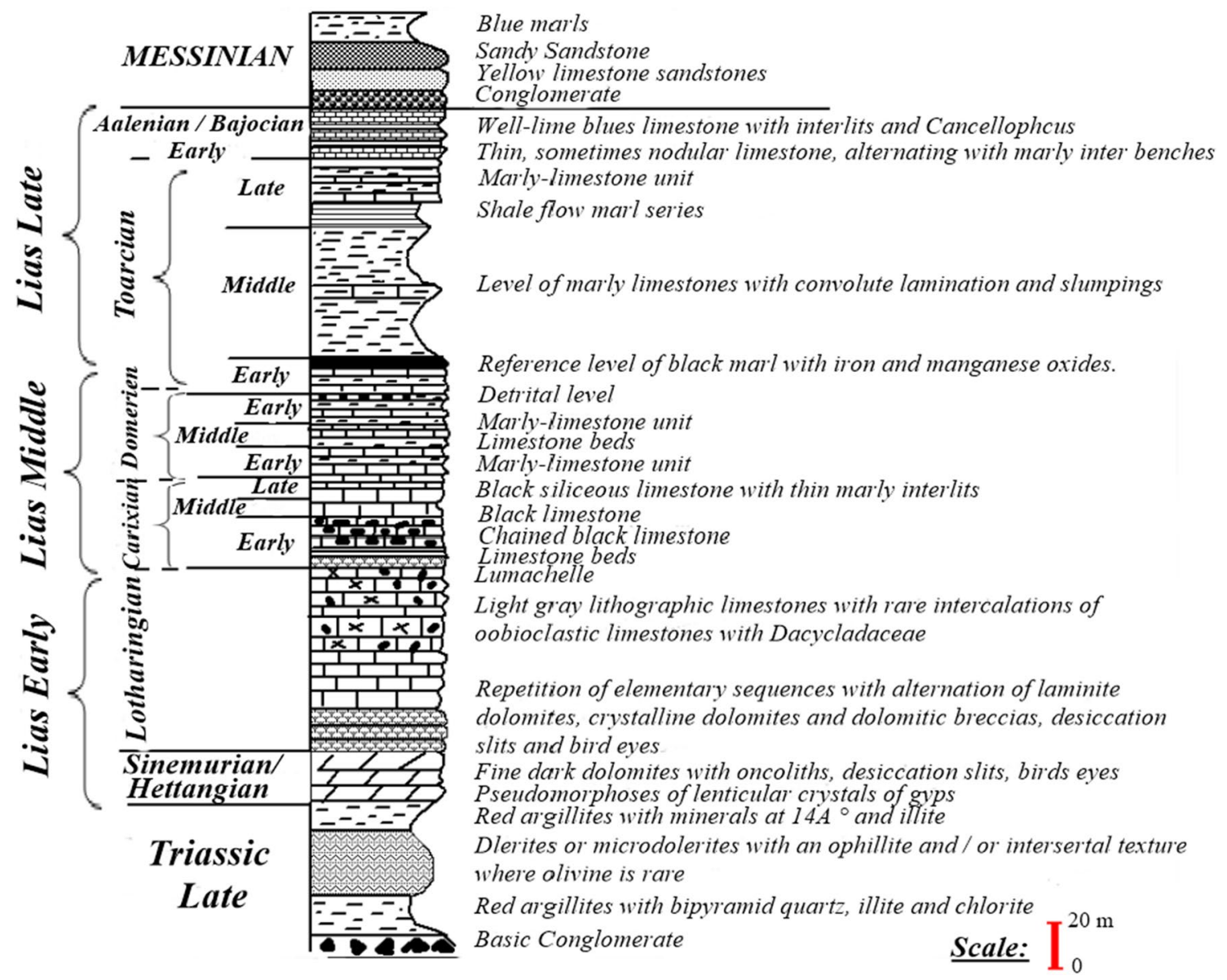

Fig. 3 Colonne stratigraphique synthétique du massif de Tazekka (Auajjar and Boulegue, 1999) 


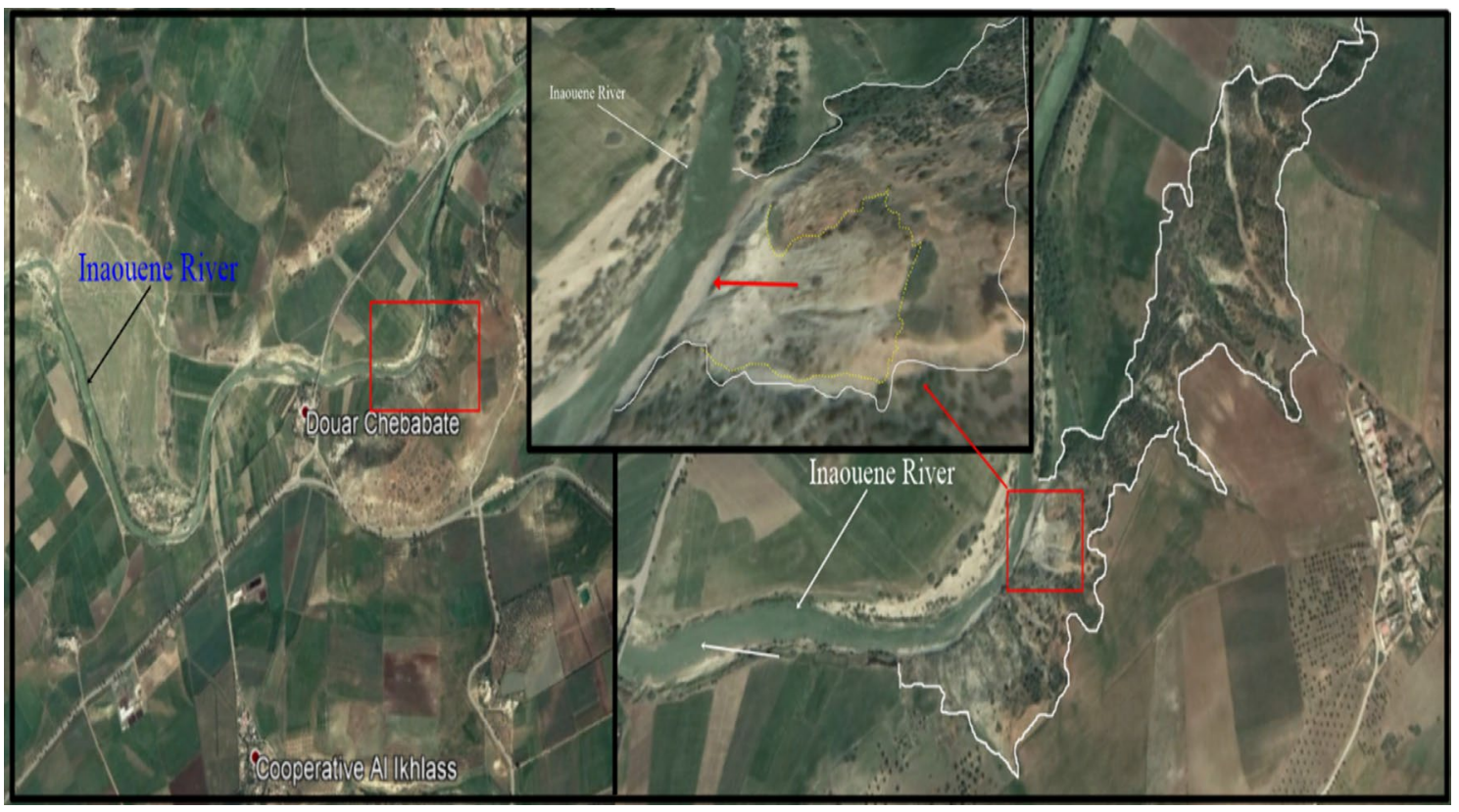

Fig. 4 Landslide at Chebabate locality

These deposits are covered by yellowish sandy marl and messenian sandstone (Fig. 5).

These sections also show a clear intra-Miocene discordance, where a level of alluvium is deposited in angular discordance on previous formations (Fig. 5), testifying to the first phase of Miocene transgression.

From the tectonic point of view, the marly formations interspersed with limestone and sandstone banks are oriented (S0) $\mathrm{N} 25-\mathrm{N} 30 / 70^{\circ} \mathrm{NW}$ to $\mathrm{N} 175-80^{\circ} \mathrm{W}$ in the northern flank and $\mathrm{N} 25-70^{\circ} \mathrm{SE}$ to N110-45SE in the southern flank (Fig. 6).

These lands are affected by numerous faults and the main ones being:

- N105-75SW faults, shifting marl and sandstone benches in normal vertical motion;

- N70-70S faults with normal vertical clearance;
Fig. 5 a Angular discordance between blue marls with limestone and sandstone intercalations and a level of alluvium; b level of alluvium with a granulation toward the summit; c Blue marl with limestone and sandstone intersections (Tortonian) affected by normal faults
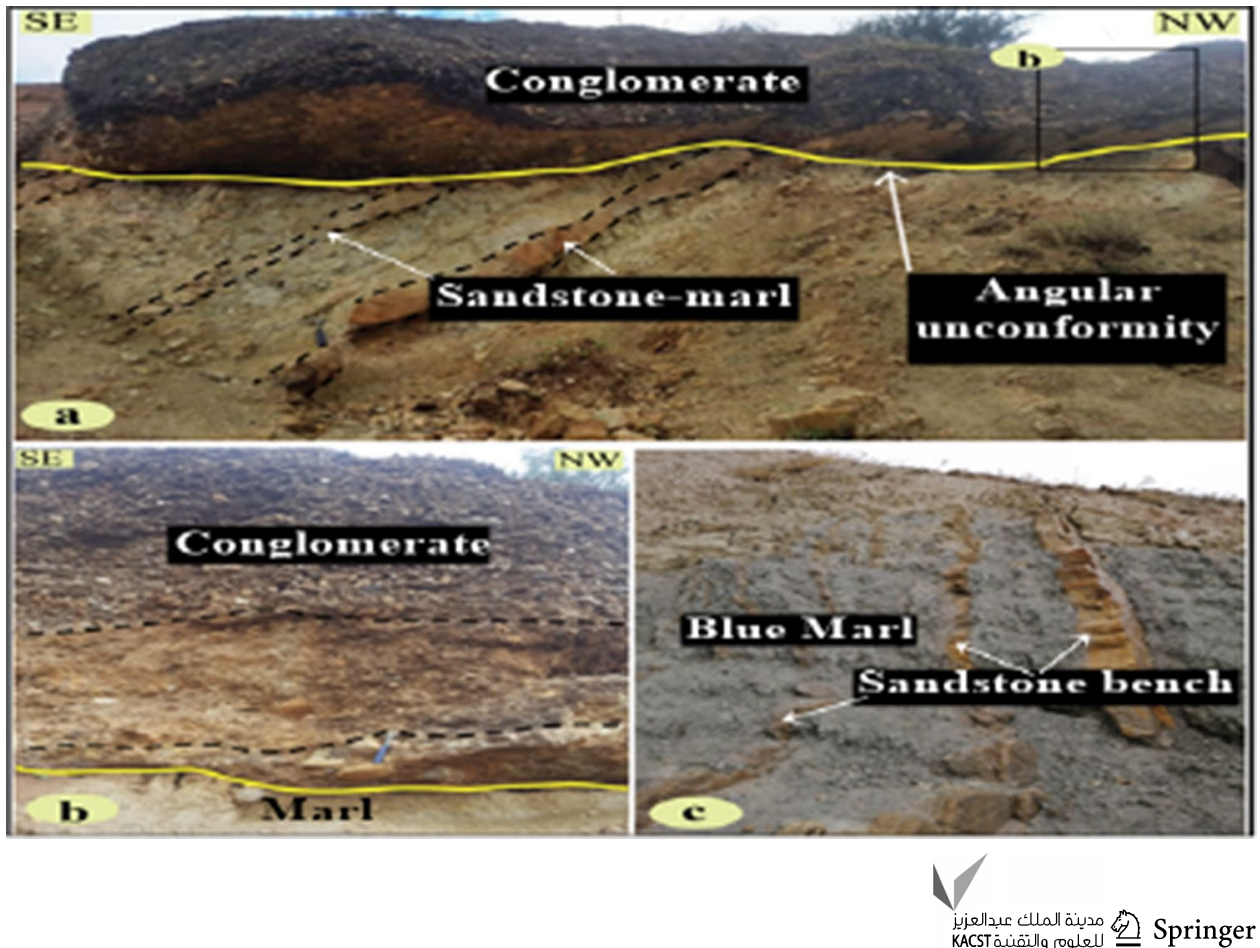


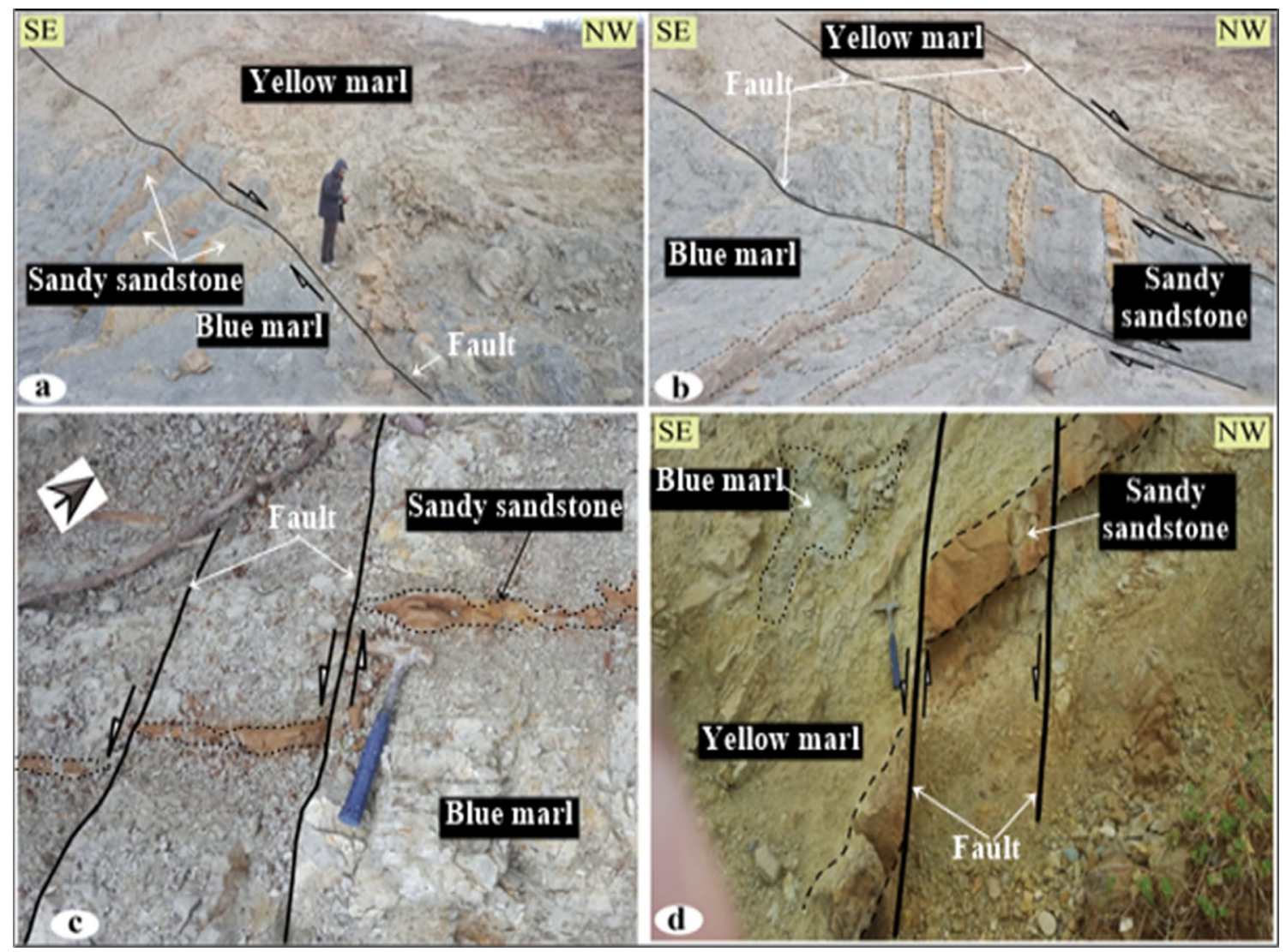

Fig. 6 Calcareous blue marl series affected by normal fault lines N70 (d), N105 (c) and N135 to N140 (a and b)

- Striking faults N140 to N160 with normal sinus clearance.

At the level of the left shore of the Inaouene River, the tectonic measurements of brittle deformation (Fig. 7) carried out within the marly layers, as well as the cartographic surveys allowed us to describe a tectonic system in N70 conjugated normal faults and N130 to N140. These faults affect the thick Miocene formations related to synsedimentary subsidence.

Our micro-tectonic analysis and the statistical processing (Fig. 8) of the measurements allowed us to highlight a paleofield of constraints which is characterized by a maximum stress $\sigma 1$ subvertical and oriented E-W to WNW-ESE.

The normal play of these faults has led to an increased risk of water erosion. The combination of tectonics, friable lithology (predominance of marl) and precipitation accelerates the degree of erosion risk, which leads to the triggering of the risk of landslide (Fig. 8).

Locality of Tahla (limestone cause) The area of Tahla is located NW of the Middle Atlas Middle Atlas accident and occupies the eastern part of the Tazekka Massif. It is characterized by mainly carbonate formations (limestones and dolomites) of lower Lias (Fig. 9) and locally by Triassic and Paleozoic terrains. Upper Miocene formations are exposed in several localities.

Indeed, this limestone plateau, also called plateau Tahla, is inclined to the north and covers an area of about $400 \mathrm{Km}^{2}$. Liasic carbonates form a monoclinal slope of $10^{\circ}$ to $30^{\circ}$ to the north and northwest (Fig. 9). These carbonates are transgressed by the Miocene deposits of the South Rifain furrow (Figs. 9, 10). On the tectonic level, this northern part of the Middle Atlas has had the same evolution as that of the entire subtabular part of the chain and is subdivided into several causses (Martin 1981).

However, its proximity to the South Rifean furrow subjected it to Miocene subsidence. Consequently, during the Late Miocene, this plateau is affected by subvertical N45 and N130 faults (Figs. 9, 10), separating a multitude of horsts and grabens related to an extensive episode. This episode allowed an intrusion of the South Rifean Sea in the northern part of the Middle Atlas (Charrière 1990; Sabaoui 1998).

During the lower Pliocene, the Tahla Cause underwent compressive tectonics, coupled with rifle thrust, which induced a generalized uplift. This uplift is responsible for a shift toward the north, and the reactivation of certain structural features. 

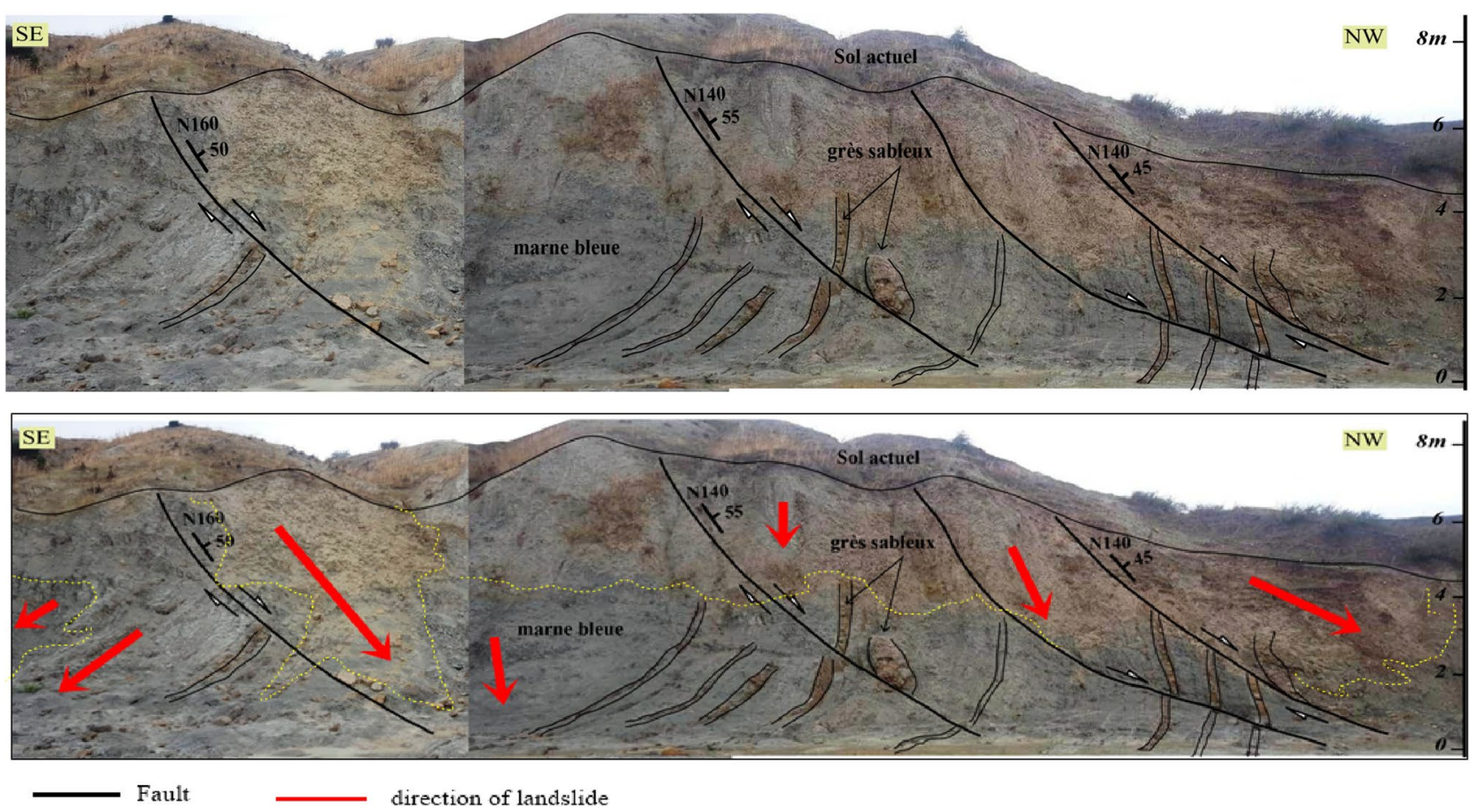

Fig. 7 Mapping a tectonic normal fault in the Chebabate area (left shore of the Inaouene River)

The N40 to N50 faults are taken up in inverse faults (Fig. 8) and those in the N120 to N140 direction in recesses (Charrière 1990). These NE-SW and NW-SE accidents remained active later, as shown by the deformation of the Pliocene and Villafranchian terrains (Charrière 1990; Sabaoui 1998). During the Quaternary, this plateau has undergone several types of digging, dissolving and backfilling.

In addition, a volcanic activity is synchronous with this tectonic activity. Since Bab Azhar, the basalt flows have spread over the Inaouene valley to cover a Pleistocene terrace higher than Lamtahene (Dridri and Fedan 2001).

\section{Conclusion}

The overall study of pattern and morphology of landslides in the Inaouene basin allows the main controlling factor of location of those landslides to be determined, i.e., the lithology and the maturity of valleys. The complex structure of the study area, straddling the Tazekka Paleozoic massif, the Middle Atlas and the South Rifean Corridor, is the result of a multiphase tectonic evolution.

Thus, the study area underwent a complex Meso-Cenozoic tectonic evolution manifested by the following tectonic phases:
- Extensive Miocene tectonics, giving rise to subvertical synsedimentary faults of N45 and N130 direction and cutting the study area into several horsts and grabens.

- Followed by a compressive phase, during the lower Pliocene, coupled with the rifle thrust, causing a generalized uplift (tilting toward the north) and the reactivation of certain structural features whose N40 to N50 faults are taken up in inverse faults and those of direction N120 to $\mathrm{N} 140$ in recesses.

- Subsequently, these NE-SW and NW-SE accidents remained active later, as evidenced by the deformation of Pliocene and Plio-Quaternary terrains. Thus, during the Quaternary, this plateau has undergone several types of digging, dissolution and backfilling.

In fact, the study of the hydrographic network, whose drains follow certain structural directions, can be considered as a good tectonic developer. In addition, changes in the course direction of some Rivers would be indicative of the reactivation of some structures, including NE-SW and NW-SE, which is consistent with structural data in the region.

In this work, it is noted that the landslides are linked to the development of the rivers and constitute a major process of slope and widening of the valley. The two-site case study provides information on the relationship between tectonic activity and soil type in landslide evolution. However, only 


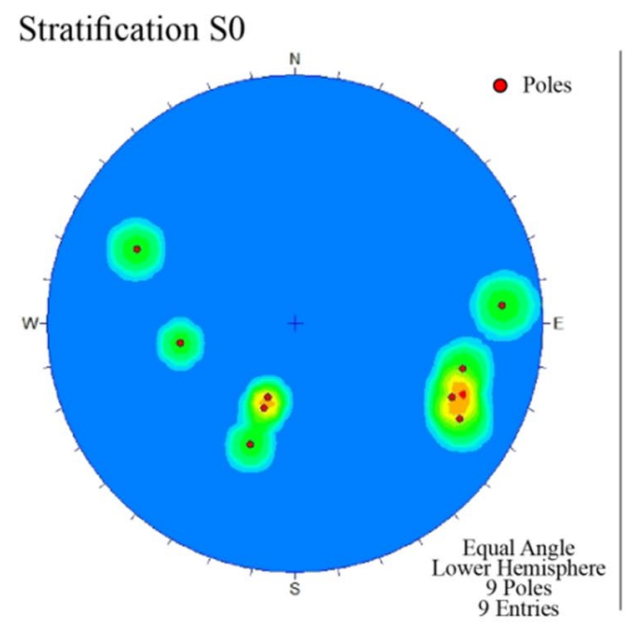

Fractures (pole)
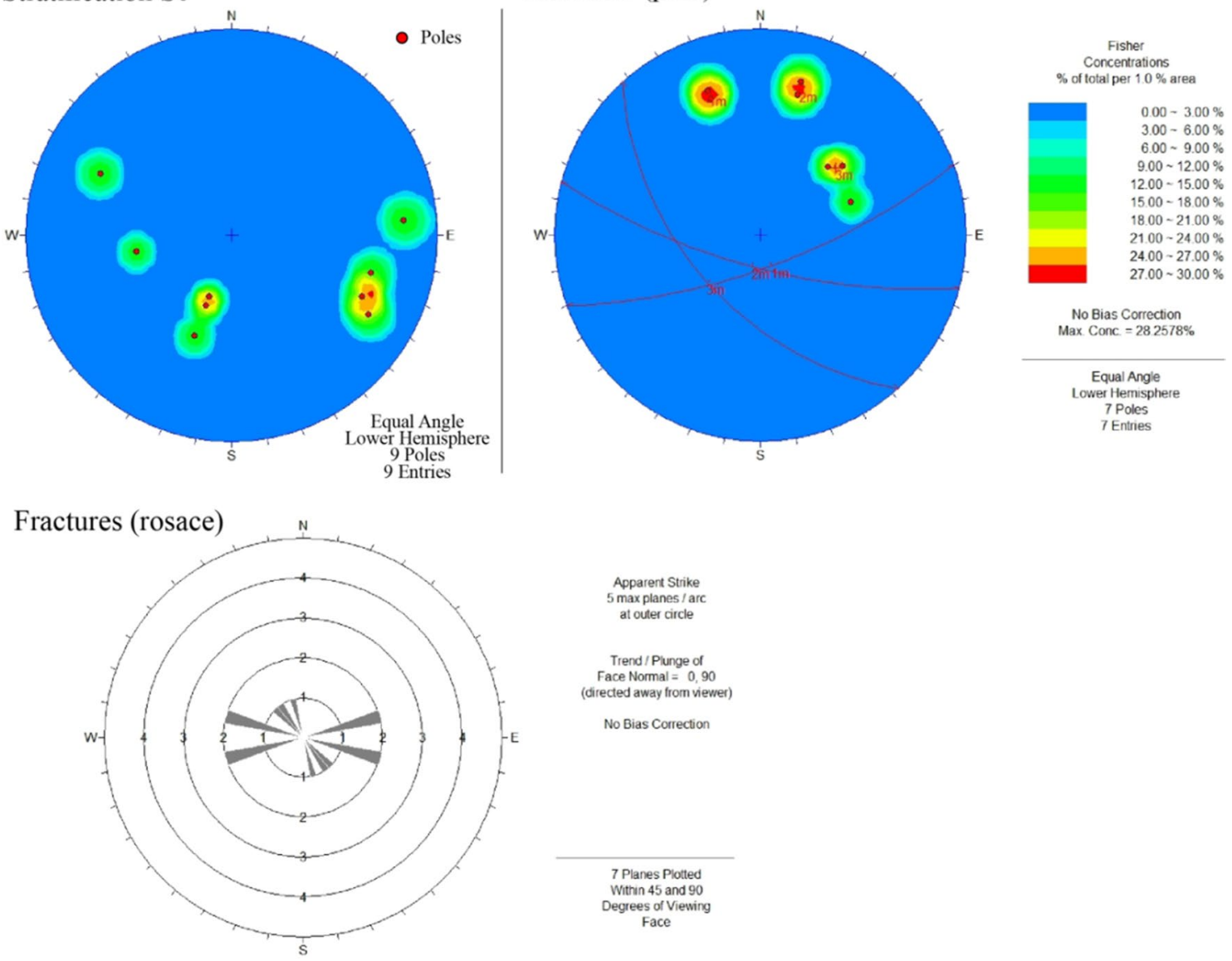

Fig. 8 Stereographic projection of tectonic measurements at the locality of Chebabate

Fig. 9 Tahla limestone plateau dislocated by a series of NE-SW faults

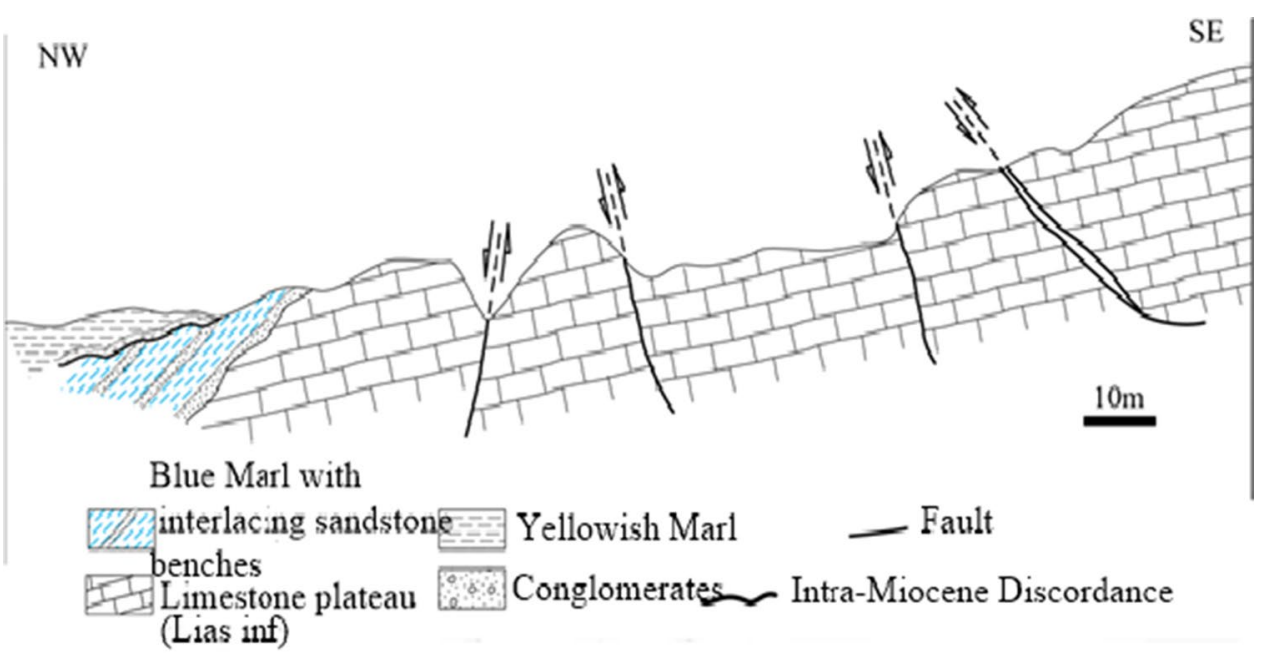

field observations can determine the extent of these movements and their consequences on the incisional power of streams or their lateral migration.

In the locality of Chebabate, the evolution of the landslide is strongly linked to the lithological nature of the geological formations, the tectonic game, the topographic (slope) and the precipitation (climate) which plays a primordial role in the evolution of the natural risks in the zone study. On the other hand, in the Causse of Tahla, which is characterized by the dominance of limestone formations, there is no risk of 
Stratification S0

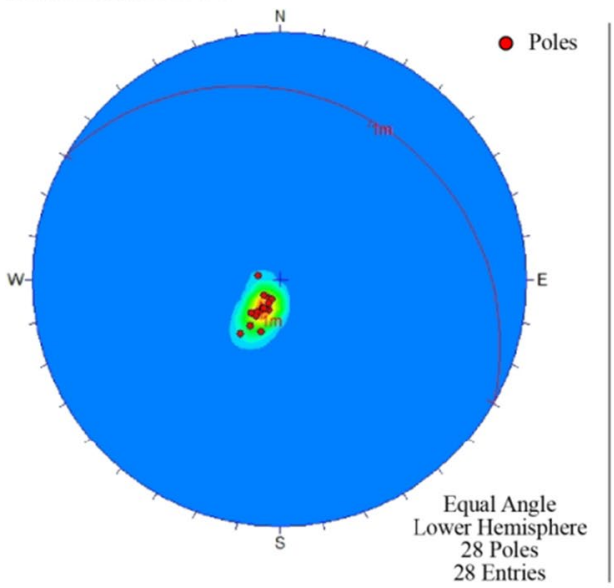

Fractures (rosace)

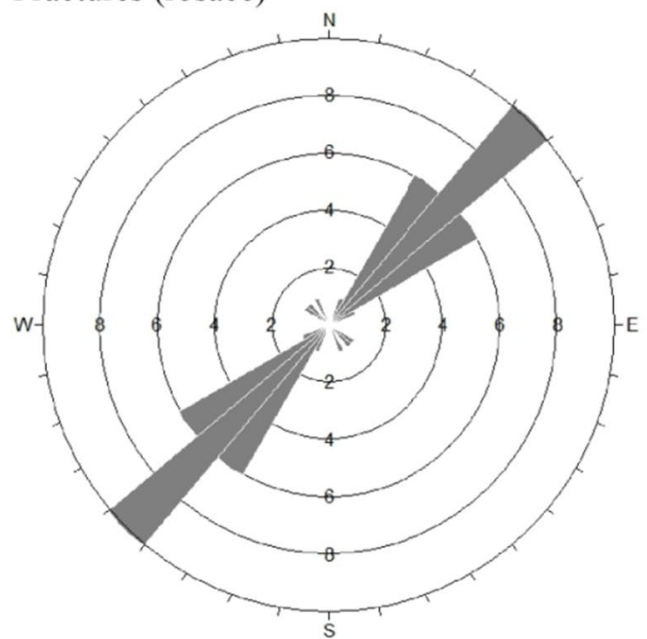

Fractures (pole)
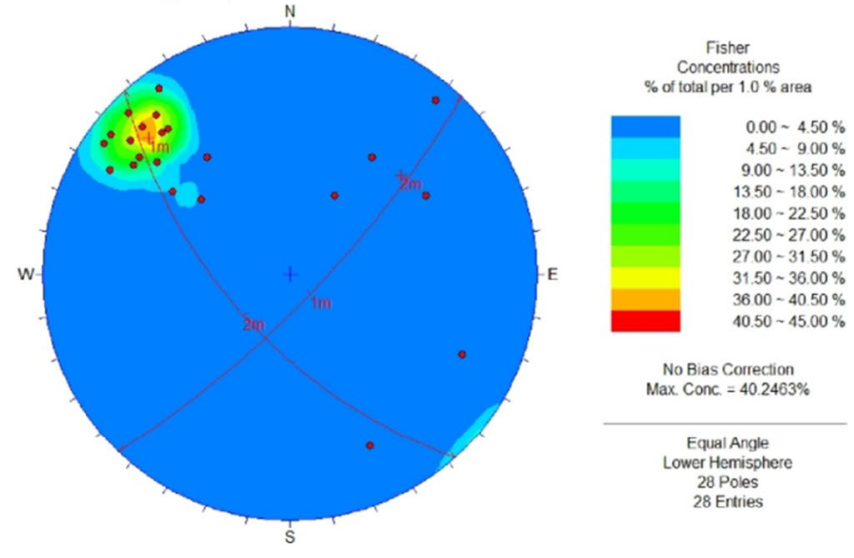

27 Planes Plotted

Within 45 and 90

Degrees of Viewing

$$
\begin{gathered}
\text { Apparent Strike } \\
10 \text { max planes / arc } \\
\text { at outer circle } \\
\text { Trend / Plunge of } \\
\text { Face Normal }=0,90 \\
\text { (directed away from viewer) }
\end{gathered}
$$

No Bias Correction

Fig. 10 Stereographic projections of families of faults in the causse of Tahla

landslides even if the effect of tectonics and precipitation in the region.

In the light of this study, it is recommended that the manager and the decision-makers take the necessary measures for the protection of watersheds in order to reduce the harmful impact of this type of natural hazards, on the environment and the population and their property.

\section{Compliance with ethical standards}

Conflict of interest The author(s) declared no potential conflicts of interest with respect to the research, authorship and/or publication of this article.
Open Access This article is licensed under a Creative Commons Attribution 4.0 International License, which permits use, sharing, adaptation, distribution and reproduction in any medium or format, as long as you give appropriate credit to the original author(s) and the source, provide a link to the Creative Commons licence, and indicate if changes were made. The images or other third party material in this article are included in the article's Creative Commons licence, unless indicated otherwise in a credit line to the material. If material is not included in the article's Creative Commons licence and your intended use is not permitted by statutory regulation or exceeds the permitted use, you will need to obtain permission directly from the copyright holder. To view a copy of this licence, visit http://creativecommons.org/licenses/by/4.0/. 


\section{Reference}

Auajjar J, Boulegue J. (1999): Les minéralisations Pb-Zn (Cu) Ba du district du Tazekka (Taza, Maroc oriental), chronique de la recherche minière, 536-537:121-135

Ballantyne CK (2002) Paraglacial geomorphology. Quatern Sci Rev 21(18):1935-2017

Benzougagh B, Boudad L, Dridri A, Sadkaoui D (2016) Utilisation Du Sig Dans L'analyse Morphométrique Et La Prioritisation Des Sous-Bassins Versants De Oued Inaouene (Nord-Est Du Maroc). Eur Sci J 12(6):234-243

Benzougagh B, Dridri A, Boudad L, Kodad O, Sdkaoui D, Bouikbane H (2017) Evaluation of natural hazard of Inaouene Watershed River in Northeast of Morocco: application of Morphometric and Geographic Information System approaches. Int J Innovation Appl Stud 19(1):85-97

Calista M, Miccadei E, Piacentini T, Sciarra N (2019) Morphostructural, Meteorological and Seismic Factors Controlling Landslides in Weak Rocks: the Case Studies of Castelnuovo and Ponzano (North East Abruzzo, Central Italy). Geosciences 9:122-131

Charrière A (1990) Héritage Hercynien et évolution géodynamique Alpine d'une chaine intracontinentale:le Moyen-Atlas au SE de Fès (Maroc). Thèse doctorale de l'Université de Toulouse, 256p

Dridri A, Fedan B (2001) Rôle du contrôle structural dans la mise en place du réseau hydrographique de Sebou et Inaouène entre Fès et Oued Amlil (Maroc). Bulletin de l"eInstitut scientifique Rabat, section Science de la Terre 23:67-77

Gajbhiye S, Mishra SK, Pandey A (2013) Effect of seasonal/monthly variation on runoff curve number for selected watersheds of Narmada Basin. Int J Environ Sci 3(6):2019-2030

Gajbhiye S, Mishra SK, Pandey A (2014) Prioritizing erosion-prone area through morphometric analysis: an RS and GIS perspective. Appl Water Sci 4(1):51-61

Gajbhiye S, Sharma SK, Tignath S, Mishra SK (2015) Development of a Geomorphological Erosion Index for Shakkar Watershed. Geol Soc India 86(3):361-370

Hovius N, Stark CP, Allen PA (1997) Sediment flux from a mountain belt derived by landslide mapping. Geology 25(3):231-234

Kumar V, Gupta V, Sundriyal YP (2019) Spatial interrelationship of landslides, litho-tectonics, and climate regime, Satluj valley, Northwest Himalaya. Geol J 54:537-551

Laik A (2016) Implementation of Stereographic and Spherical Projection in Structural Geology with JavaScript and the web through. Svg Net. https://doi.org/10.13140/RG.2.1.3546.9848
Martin J (1981) "Le moyen Atlas Central. Étude Géomorphologique", Notes et Mémoire Service de Géologie Maroc, 258-445

Meshram SG, Meshram C (2020) Probabilistic estimation of design runoff curve number: a case study for Shakkar River Watershed, India. Int J Hydrol Sci Technol 10(3):302-313

Meshram SG, Powar PL, Singh VP (2017) Modelling soil erosion from a watershed using cubic splines. Arab J Geosci 10:155-168

Mukhlisin M, Khiyon KN (2018) The effects of cracking on slope stability. J Geol Soc India 91(6):704-710

Sabaoui A (1998) Rôle des inversions dans l'évolution méso-cénozoïque du Moyen Atlas septentrional (Maroc). L'exemple de la transversale El Menzel-Ribat Al Khayr-Bou Iblane. Thèse Sci., 432p

Sanchez G, Rolland Y, Corsini M, Braucher R, Bourlès D, Arnold M, Aumaître G (2010) Relationships between tectonics, slope instability and climate change: cosmic ray exposure dating of active faults, landslides and glacial surfaces in the SW Alps. Geomorphology 117:1-13

Shroder JF (1998) Slope failure and denudation in the western Himalaya. Geomorphology 26(1):81-105

Song H, Cui W (2016) A large-scale colluvial landslide caused by multiple factors: mechanism analysis and phased stabilization. Landslides 13(2):321-335

Tribak A, Garouani A, Abahrour ML (2012) 'Érosion hydrique dans les séries marneuses tertiaires du prérif oriental: agents, processus et évaluation quantitative. Revue Marocaine des Sciences Agronomiques et Vétérinaires 1(1):47-52

Utili S (2013) Investigation by limit analysis on the stability of slopes with cracks. Geotechnique 63(2):140-154

Wu LZ, Huang RQ, Xu Q, Zhang LM, Li HL (2015) Analysis of physical testing of rainfall-induced soil slope failures. Environ Earth Sci 73(12):8519-8531

Zeng L, Liu J, Zhang JH, Bian HB, Lu WH (2018) Effect of colluvial soil slope fracture's anisotropy characteristics on rainwater infiltration process. Adv Civ Eng. Article ID 7351628, 11 pages https ://doi.org/10.1155/2018/7351628

Zeng L, Xiao LY, Zhang JH, Gao QF (2020) Effect of the characteristics of surface cracks on the transient saturated zones in colluvial soil slopes during rainfall. Bull Eng Geol Environ 79:699-709. https://doi.org/10.1007/s10064-019-01584-1

Publisher's Note Springer Nature remains neutral with regard to jurisdictional claims in published maps and institutional affiliations. 